603

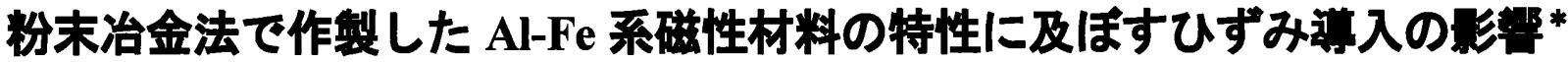

\author{
渡邊 隆 ${ }^{* 1}$, 久保田 正広 ${ }^{* 2}$
}

\section{Effect of strain on properties of Al-Fe based magnetic materials produced by powder metallurgy process}

\author{
Takashi WATANABE ${ }^{* 1}$ and Masahiro KUBOTA \\ ${ }^{* 1}$ Graduate School of Industrial Technology, Nihon university \\ 1-2-1 Izumi-cho, Narashino-shi, Chiba, 275-8575 Japan
}

\begin{abstract}
Four different powders were produced; pure aluminum together with iron powders were mechanically alloyed (MAed); each elemental powder was mechanically milled (MMed); only pure aluminum powder was MMed, and subsequently MMed powder was added to pure iron powder; each elemental powder was mixed (Mixed): The all powders were consolidated into bulk materials by spark plasma sintering (SPS). Effects of MA, MM+MM, MM or Mix processes on magnetic properties of the SPS materials were evaluated by vibrating sample magnetometer. The formation of $\mathrm{Al}_{5} \mathrm{Fe}_{2}$ was observed in MA and MM+MM SPS materials. On the other hand, the aluminide compounds were not formed in the MM SPS material and Mix SPS material. Formation and amount of the aluminide compounds were controlled by changing the process from MA to MM processing. As a result of suppression of formed alminide compounds, magnetic properties were improved in the SPS materials fabricated from powders produced by MM for only pure aluminum and Mix powder.
\end{abstract}

Key Words : Mechanical Alloying, Mechanical Milling, Spark Plasma Sintering, Aluminum, Iron

\section{1. 精}

近年，アルミニウムの高強度化と高機能化を同時に達成するために，メカニカルアロイング（MA）法と放電 プラズマ焼結（SPS）法を組み合わせたプロセス（MA-SPS）による材料開発が積極的に行われている(1).ボール ミルを用いる MA 法は，2 種類以上の粉末を固相状態のまま，攪䢁，混合するプロセスで，複合粉末を作製する のに適している. また，ナノレベルの組織形成が可能である. 一方，単一元素の粉末を作製する場合はメカニカ ルミリング（MM）法と呼ばれる. SPS 法は, 粉末間に放電現象を発生させ, 粉末表面の酸化膜などの破壊とジ ユール熱によってバルク材（SPS 材）を作製するプロセスである.

著者らは，これまでに MA 処理または MM 処理で得られた粉末を SPS 装置で固化成形することで, Al-Fe 系磁 性材料を創製した，しかし，添加した純鉄が高温で焼結中にアルミニウムと固相反応し，その量が減少してしま うため，磁気特性が低下した (2)(3)，そこで，磁気特性の低下を抑制するために，粉末の作製プロセスを MA 法か ら MM 法へ変更することで, アルミニウムと純鉄の固相反応を抑制することを試みた ${ }^{(3)}$.

本研究では，固相反応をさらに抑制するために，MM 処理を施す材料を純アルミニウムのみに変更し，その後 MM 処理を施していない純鉄を混合することで混合粉末を作製した. また，MM 処理を施さずに純アルミニウム および純鉄粉末を混合した混合粉末を作製した.これらの粉末を SPS 装置で固化成形した. 得られた SPS 材の磁 気特性を調べ，原料粉末の違いが磁気特性に及ぼす影響を明らかにすることを目的とした.

\section{2. 実分方法}

純度 $99.9 \%$, 平均粒子径 $39.2 \mu \mathrm{m}$ の純アルミニウム粉末と純度 $99.9 \%$, 平均粒子径 $46.7 \mu \mathrm{m}$ の純鉄粉末を出発 原料として用いた. MM 処理には振動型ボールミル SPEX 8000 を用い, $2 \mathrm{~h}$ 処理した. 得られた MM 粉末に対 して純鉄の配合組成は 10，30 および 50 mass\%とし，工具鋼製容器内に MM 粉末および純鉄粉末を装入した.

\footnotetext{
${ }^{* 1}$ 学生員, 日本大学大学院 生産工学研究科 機械工学専攻（†275-8575 千葉県習志野市泉町 1-2-1）

*2 正員, 日本大学 生産工学部 機械工学科

E-mail: kubota.masahiro@nihon-u.ac.jp
} 
その後, 振動型ボールミルを用いて $0.5 \mathrm{~h}$ 混合処理を施し, 混合粉末を作製した. 作製した粉末を黒鈆ダイス (外 径 : $50 \mathrm{~mm}$, 内径 : $20.1 \mathrm{~mm}$, 高さ : $40 \mathrm{~mm}$ ）に $5 \mathrm{~g}$ 充填し, SPS 装置を使用して, 真空中で $15.4 \mathrm{kN}$ を負荷し, 焼結温度 $673 \mathrm{~K}, 773 \mathrm{~K}$ および $873 \mathrm{~K}$ で $1 \mathrm{~h}$ 保持し, SPS 材（直径 : $20 \mathrm{~mm}$ ，高さ : $5 \mathrm{~mm}$ ）を作製した.

X 線回折装置を用いて SPS 材に存在する化合物相を同定した. 測定は $40 \mathrm{kV}, 60 \mathrm{~mA}$ の CuK $\alpha$ 線を用いて，回折 速度 $1.67 \times 10^{-2} \circ / \mathrm{s}$ および回折角度 $2 \theta=20 \sim 80^{\circ}$ の条件で行った. SPS 材の磁気特性を評価するために，振 動試料型磁力計を用い, $800 \mathrm{kA} / \mathrm{m}$ または $40 \mathrm{kA} / \mathrm{m}$ の磁界中で, 飽和磁束密度および保磁力を測定した. 試験片は, SPS 材を機械加工により $6 \times 4 \times 1 \mathrm{~mm}^{3}$ とし，磁気測定に供した.

\section{3. 実跧結果および孝菜}

図 1 に異なるボールミル処理から得られた Al-30％ Fe 粉末を固化成形した SPS 材の X 線回折結果を示す。こ れまでのボールミル処理で得られた粉末，すなわち，MA 粉末およびMM 粉末同士を混合させた粉末（MM 混合 粉末）から作製した SPS 材では， $\mathrm{Al}_{5} \mathrm{Fe}_{2}$ の生成が認められたが(2) (3)，本研究で作製した SPS 材は化合物の生成は 認められなかった．この結果は，原料粉末を作製するプロセスの変更によって，固相反応が抑制されたことを示 唆している.

図 2 に異なるボールミル処理から得られた粉末を焼結温度 $673 \mathrm{~K}$ で固化成形した SPS 材の磁気特性を示す. ボ 一ルミル処理を施していない混合粉末を固化成形した SPS 材が最も高い飽和磁束密度を示し，一方, 保磁力は最 も低い值を示した. 図 1 に示したようにアルミナイド化合物の生成が抑制されたため高い飽和磁束密度を示した と考えられる. 一方, 低い保磁力は，不純物や格子欠陥の挙動に敏感であるため ${ }^{4)}$, ボールミル処理によって導 入されるひずみの量が異なることに起因していると考えられる.

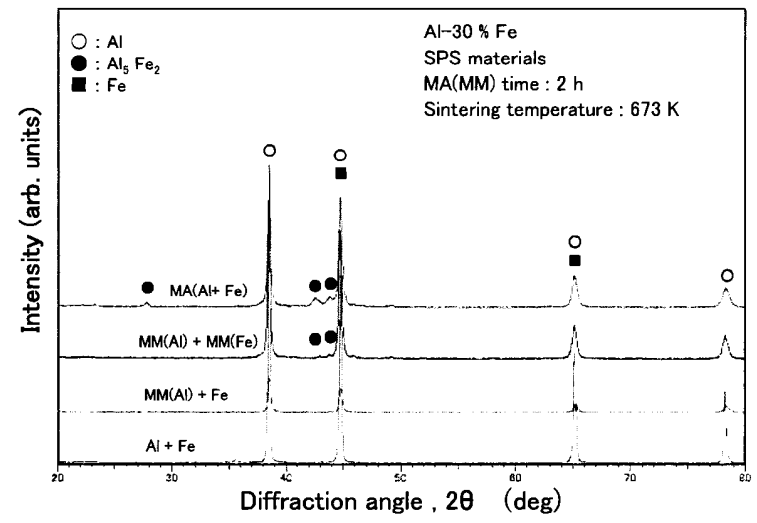

Fig. 1 X-ray diffraction patterns of Al-30 mass\% Fe SPS materials fabricated from $2 \mathrm{~h}$ powder at different ball milling process.

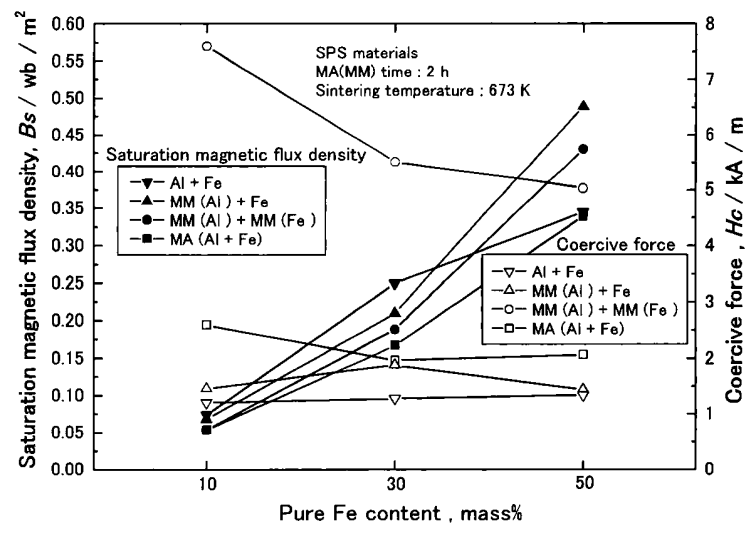

Fig. 2 Change in the saturation magnetic flux density and coercive force for the SPS materials fabricated from $\mathrm{Al}-\mathrm{X}$ mass $\%$ Fe powders $(X=10,30,50)$ produced by different ball milling processes at $673 \mathrm{~K}$.

\section{4. 結}

$\mathrm{Al}-\mathrm{Fe}$ 系粉末を作製する際のボールミル処理条件を変更することによって, SPS による固化成形中に固相反応 を抑制することができた，その結果，磁気特性を改善することができた．このことから，最適な粉末作製条件を 選択することで, 優れた磁気特性を有するアルミニウム基磁性材料を創製できる可能性が示された.

\section{文献}

(1) M. Kubota, "Properties of nano-structured pure Al produced by mechanical grinding and spark plasma sintering", Journal of Alloys and Compounds., Vol. 434-435, (2007), pp. 294-297.

(2) 渡邉 隆, 久保田 正広,日本機械学会 2012 年度年次大会講演論文集,12-1(2012),S041021.

（3）渡邊 隆，久保田 正広,日本機械学会関東支部第 19 期総会講演会講演論文集,130-1(2013),pp. 199-200.

(4) 小沼稔, 磁性材料,工学図書,(1996),pp. 53-54. 